\title{
Production of Xanthanases by Paenibacillus spp.: Complete Xanthan Degradation and Possible Applications
}

\author{
Simin Ashraf ${ }^{1}$, Mohammad Reza Soudi ${ }^{1 *}$, Parinaz Ghadam ${ }^{2}$ \\ ${ }^{1}$ Department of Microbiology, Faculty of Biological Sciences, Alzahra University, Tehran, Postal code:1993893973. Iran \\ ${ }^{2}$ Department of Biotechnology, Faculty of Biological Sciences, Alzahra University, Tehran, Postal code:1993893973 Iran
}

"Corresponding author: Mohammad Reza Soudi. Alzahra University, Vanak, Tehran, Iran. Tel: +98-21-88044058-9 (2441);

Fax:+98-21-88058912; E-mail: msoudi@alzahra.ac.ir, soudimr@gmail.com

Received:10 Feb. 2016; $\quad$ Revised: 8 Jan. 2017; $\quad$ Accepted: 19 June 2017; $\quad$ Published online: 19 August 2017

\begin{abstract}
Background: A number of microorganisms and their enzymes have been reported as xanthan depolymerizers. Paenibacillus species are well-known polysaccharide hydrolyzing bacteria. However, Paenibacillus alginolyticus and Paenibacillus sp. $\mathrm{XD}$ are the only species in the genus which are now known to degrade xanthan.

Objectives: Complete biodegradation of the xanthan exopolysaccharide is a rarely found capability among microorganisms. The aim of this study is to survey xanthanase producing bacteria with an appropriate bioactivity for the biopolymer degradation under different environmental conditions.

Materials and Methods: The bacteria were isolated based on viscosity reduction of the xanthan solution. Bacterial isolates were identified using rep-PCR (repetitive element-based genomic fingerprinting) and $16 \mathrm{~S}$ rDNA sequencing. Xanthanases were characterized by measuring their activity at different temperatures, $\mathrm{pH}$ values, and $\mathrm{NaCl}$ concentrations. Degradation of other polysaccharides and xanthan degradation products were investigated based on the screening plate method and TLC (thin-layer chromatography), respectively.

Results:Six isolates from different Paenibacillus species with a complete xanthan degrading capability were isolated from Urmia Lake. Phylogenetic analysis placed these strains within the genus Paenibacillus with the closest relatives that were found to be $P$. nanensis, $P$. phyllosphaerae, $P$. agaridevorans, $P$. agarexedens, and $P$. taohuashanense. These isolates displayed different levels of the xanthan biodegradation activity in temperatures ranging from 15 to $55^{\circ} \mathrm{C}$ and $\mathrm{pH}$ values from 4 to 11. Xanthanolytic activity was generally prevented in presence of $\mathrm{NaCl}\left(>0.1 \mathrm{~mol} . \mathrm{L}^{-1}\right)$. Furthermore, the isolated Paenibacillus spp. could degrade several other polysaccharides including xylan, CMC (carboxymethyl cellulose), starch, alginate, and pectin.

Conclusion: Novel strains of the six different Paenibacillus species that were introduced in the present study are able to produce xanthanases with interesting characteristics. In light of the results from this study, special applications, particularly in healthcare, medicine, and the environment is hereby proposed for these enzymes.
\end{abstract}

Keywords: Bacterial enzymes, Biodegradation, Paenibacillus spp., Xanthan lyase, Xanthanase

\section{Background}

Xanthan is a bacterial slime polysaccharide, produced by different species of the genus Xanthomonas. Xanthan has a cellulosic backbone and a linear chain consisting of the sequence of mannosyl-glucuronylmannose attached at the $\mathrm{C}-3$ position on the alternate glucosyl residue of the backbone. The proximal and distal mannosyl residues of the side chain are frequently acetylated and pyruvylated, respectively. Resistance to heat, stability in acidic and alkaline media, and the superior rheological properties make it possible to use this indigestible biopolymer in food, pharmaceuticals, environment, petroleum and chemical industries (1). This microbial biopolymer is not easily degraded by microorganisms. Since the 1960s and shortly after industrial production of xanthan gum, a number of microorganisms and their enzymes have been reported as xanthan depolymerizers. Until now, the xanthan degrading bacteria that were reported in the literature were 
found to belong to the 10 different genera capable of complete or partial degradation of the xanthan macromolecules: a Bacillus sp. (2), Corynebacterium sp. (NCBI 11535) (3), Bacillus sp. K11 (4) and Bacillus GL1 (5), Paenibacillus alginolyticus XL-1 (6), Cellulomonas sp. LX (7), Microbacterium sp. XT11 (8), isolates of Brevibacillus thermoruber, Anoxybacillus flavithermus and Anoxybacillus rupiensis (9), and Enterobacter sp. nov. LB37 (10). Furthermore, xanthan degradation by bacterial consortia and mixed cultures has also been reported (11-13).

Xanthanase is a name collectively used for a group of enzymes invading xanthan backbone and its side chains, eventually resulting in the complete xanthan degradation. Xanthan lyase, one of these enzymes, truncates side chains of xanthan molecules by removal of their distal mannose residues.

Most of the xanthan degrading bacteria have been isolated from the soil. Other environments such as hot springs (9) and activated sludge (14) provide the opportunity to explore novel xanthan degrading species. The present study has focused on bacterial xanthanses, a group of inadequately studied polysaccharide degrading enzymes, in soil and sludge of Urmia Lake, Iran.

\section{Objectives}

The aim of this research is to study xanthan degrading microorganisms and their xanthanase enzymes. Urmia Lake, with a salinity ranging between 120 to $280 \mathrm{~g} . \mathrm{L}^{-1}$, is a unique life reservoirs. The discovery of native strains with novel enzymatic features provides new prospects for the applications of the polysaccharide degradation in different fields of study.

\section{Materials and Methods}

\subsection{Bacterial Strains and Phenotypic Characterization}

Naturally sun-dried benthic sludge and soil samples were collected from Urmia Lake in West Azerbaijan Province, Iran. One gram aliquots of the samples were transferred into $500-\mathrm{mL}$ conical flasks containing $100 \mathrm{~mL}$ Xanthan Selective (XS) broth as the enrichment culture. XS broth was formulated using a mineral salts solution (MSS) containing $500 \mathrm{mg} . \mathrm{L}^{-1} \mathrm{CaCl}_{2}, 50 \mathrm{mg} \cdot \mathrm{L}^{-1} \mathrm{~K}_{2} \mathrm{HPO}_{4}, 800$ $\mathrm{mg} . \mathrm{L}^{-1} \mathrm{NaCl}, 25 \mathrm{mg} \cdot \mathrm{L}^{-1} \mathrm{MgSO}_{4} \cdot 7 \mathrm{H}_{2} \mathrm{O}$, and $700 \mathrm{mg} . \mathrm{L}^{-1}$

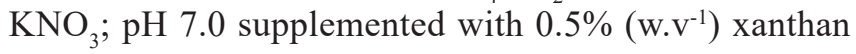
as the sole source of carbon and energy. The enrichment cultures were incubated in shaking incubator at $30{ }^{\circ} \mathrm{C}$ and 150 rev. $\mathrm{min}^{-1}$. After reduction of the viscosity which indicates xanthan degradation, a 10-fold serial dilution of enrichment culture was spread on Xanthan
Yeast (XY) plates and incubated at $30{ }^{\circ} \mathrm{C}$ overnight (7). $\mathrm{XY}$ agar was formulated using MSS containing (w. $\left.\mathrm{v}^{-1}\right)$ xanthan $(0.3 \%)$, yeast extract $(0.05 \%)$, and agar $(1.5 \%)$. Colonies with the halo zone were selected and purified. These bacterial isolates were cultured in the XY broth at $30{ }^{\circ} \mathrm{C}$ and 150 rev. $\mathrm{min}^{-1}$. Final viscosity of each culture was measured by Brookfield viscometric system using spindle No. 3 under 60 rev. $\mathrm{min}^{-1}$ rotation at an ambient temperature.

Those cultures with a remarkable reduction in the viscosity were selected for further experiments. Phenotypic characteristics including Gram reaction, sporulation capability plus catalase, and oxidase tests were determined using the standard procedures.

In addition to the isolated strains, three type species of Paenibacillus spp. including Paenibacillus agaridevorans (IBRC-M 10934), Paenibacillus nanensis (DSM 22867), and Paenibacillus phyllosphaerae (IBRC-M 10879) were examined for their xanthanolytic activity.

\subsection{Genomic Study}

Total genomic DNA of the isolates was extracted using the cetyltrimethylammonium bromide (CTAB) method (15). Rep-PCR was carried out to assess the diversity of the isolates and to allow the selection of one representative strain from each of the discriminated species using a previously described procedure and appropriate primers, REP1R-I (16) and REP2-I (17).

The DNA fingerprints of the strains obtained by rep-PCR were compared by visual inspection of the banding patterns. The amplification products were transformed into digits of binary matrices and analyzed using NTSYS-pc, version 2.02e. Jaccard's similarity coefficients were calculated by the SIMQUAL program and these data were subjected to the UPGMA cluster analysis using the SAHN program.

The amplified 16S rDNA sequences (18) were compared with the reference sequences obtained from EzTaxon server using the BLAST algorithm (19). Multiple alignments were performed using the Clustal $\mathrm{W}$ program (20). The phylogenetic tree was constructed based on the neighbor joining method (21) using the software package MEGA 5.0 (22). The reliability of the tree topology was evaluated by bootstrap analysis (23) based on 1000 replications.

\subsection{Xanthan Degrading Enzymes}

\subsubsection{Crude Enzyme Preparation}

The supernatant of the cultures grown in the XY broth was used as the crude enzyme for further analyses using the procedure of Liu et al. (7). 


\subsubsection{Xanthanase Characterization}

Xanthanase in the crude enzyme extract was measured using $0.5 \%$ xanthan in different buffer solutions (20 mmol. $\mathrm{L}^{-1}$ ) at $15-50^{\circ} \mathrm{C}$, and sodium chloride concentrations $\leq 1$ mol. $L^{-1}$. Equal volumes of the culture's supernatant and the xanthan solutions (each $100 \mu \mathrm{L}$ ) were mixed and incubated at the above temperatures for $15 \mathrm{~min}$. The reducing sugars were measured using di-nitrosalicylic acid (DNS) method $(24,25)$.

To determine the optimal $\mathrm{pH}$ of enzyme activity, the experiments were carried out at $30{ }^{\circ} \mathrm{C}$ in the $\mathrm{pH}$ range of 4 to 11, while citrate buffer was used to adjust $\mathrm{pH}$ from 4 to 6 , phosphate buffer from 6 to 7 , tris buffer from 7 to 9, and carbonate-bicarbonate from 10 to 11 .

\subsubsection{Enzyme Assay}

The total xanthanase activity was measured using $0.5 \%$ xanthan in an appropriate buffer, optimum temperature without additional $\mathrm{NaCl}$. Xanthan lyase activity was determined by measuring the increase in absorbance at 235 $\mathrm{nm}(5,6)$. Crude enzyme $(100 \mu \mathrm{L})$ was added to $500 \mu \mathrm{L}$ xanthan solution $\left(0.05 \%\right.$ xanthan in 20 mmol. $\mathrm{L}^{-1}$ tris- $\mathrm{HCl}$ buffer $\mathrm{pH}$ 7.0), mixed quickly, and the related absorbance at $235 \mathrm{~nm}$ wavelength was recorded continuously for $1 \mathrm{~min}$ at $30^{\circ} \mathrm{C}$. One unit of xanthanase corresponds to the amount of enzyme required to release $1 \mu \mathrm{mol}$ of reducing sugar per minute. One unit of xanthan lyase was defined as the amount of enzyme required to produce an increase of 1.0 unit in the absorbance at $235 \mathrm{~nm}$ per min.

\subsubsection{Depolymerization Products}

To determine the degradation products, filter sterilized crude extracellular enzyme(s) and xanthan solution $(0.5 \%$ xanthan in 20 mmol. $\mathrm{L}^{-1}$ sodium phosphate buffer $\mathrm{pH} 7.0$ ) $\left(1: 4\right.$ v.v $\left.{ }^{-1}\right)$ were mixed and incubated at $30^{\circ} \mathrm{C}$ for $72 \mathrm{~h}$. The products were analyzed by TLC on silica gel plates (26).

\subsection{Polysaccharase Activity}

Plate screening method based on complex formation between polysaccharide and dye: congo red, lugol's iodine, and ruthenium red were used to determine polysaccharide degrading activity among the selected strains of the Paenibacillus species using CMC, xylan, starch, pectin or alginate as the substrate $(6,27-31)$.

\subsection{Statistical Analysis}

Data from the characterized xanthanases at different temperatures, $\mathrm{pH}$ values, and $\mathrm{NaCl}$ concentrations were analyzed statistically using Minitab 16 software. Statistical analyses were performed by Student's t-test, one-way ANOVA and differences were considered to be statistically significant when $\mathrm{p}$ was $>0.05$.

\section{Results}

\subsection{Xanthan Degrading Bacteria}

Based on the intensive reduction in the viscosity of the broth culture, only ten out of seventy-six isolates were found to have the potential to degrade xanthan completely. Isolates were Gram positive or Gram variable, sporeforming rods, catalase, and oxidase positive.

A rep-PCR fingerprint was generated from REP primers and a dendrogram obtained using rep-PCR fingerprints as shown in Figure 1. It was assumed
A

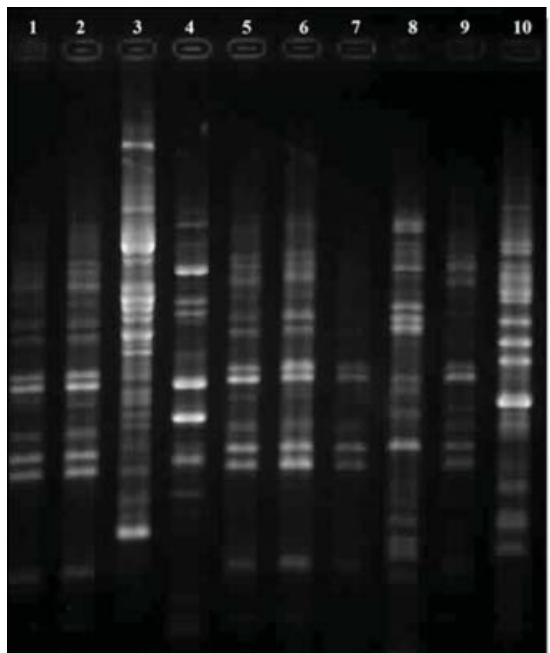

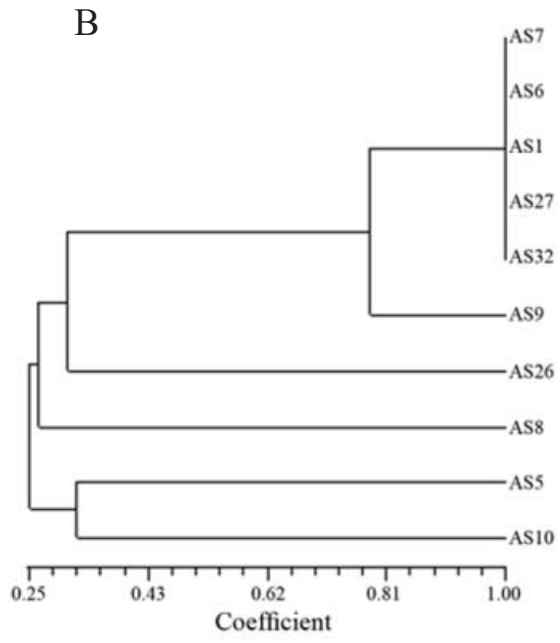

Figure 1. Gel electrophoretic image of the rep-PCR fingerprints generated by using REP primers (A): Lanes: 1 (AS7); 2 (AS6); 3 (AS5); 4 (AS26); 5 (AS1); 6 (AS27); 7 (AS32); 8 (AS8); 9 (AS9); 10 (AS10). The related dendrogram was obtained by applying UPGMA clustering method using NTSYS-pc version 2.02e (B) 
Table 1. The similarity levels of $16 \mathrm{~S}$ rDNA sequences of xanthan degrading strains of the Paenibacillus spp. presented in this study with those of the closest type species

\begin{tabular}{|c|c|c|}
\hline Query: Accession No. & Closest match : Accession No. & Similarity $(\%)$ \\
\hline $\begin{array}{l}\text { Paenibacillus sp. AS 5: } \\
\text { KT429626 }\end{array}$ & $\begin{array}{l}\text { P. nanensis } \mathrm{MX} 2-3^{(\mathrm{T})} \text { : } \\
\text { AB265206 }\end{array}$ & 97.63 \\
\hline $\begin{array}{l}\text { Paenibacillus sp. AS } 7 \text { : } \\
\text { KT429627 }\end{array}$ & $\begin{array}{l}\text { P. phyllosphaerae PALXIL04(T): } \\
\text { AY598818 }\end{array}$ & 98.04 \\
\hline $\begin{array}{l}\text { Paenibacillus sp. AS 8: } \\
\text { KT429628 }\end{array}$ & $\begin{array}{l}\text { P. agaridevorans DSM } 1355^{(\mathrm{T})} \text { : } \\
\text { AJ } 345023\end{array}$ & 98.12 \\
\hline $\begin{array}{l}\text { Paenibacillus sp. AS 9: } \\
\text { KT429629 }\end{array}$ & $\begin{array}{l}\text { P. phyllosphaerae PALXIL04(T): } \\
\text { AY } 598818\end{array}$ & 97.34 \\
\hline $\begin{array}{l}\text { Paenibacillus sp. AS 10: } \\
\text { KT429630 }\end{array}$ & $\begin{array}{l}\text { P. agarexedens DSM } 1327^{(\mathrm{T})} \text { : } \\
\text { AJ345020 }\end{array}$ & 99.11 \\
\hline $\begin{array}{l}\text { Paenibacillus sp. AS 26: } \\
\text { KT429632 }\end{array}$ & $\begin{array}{l}\text { P. taohuashanense gs65(T): } \\
\text { JQ694712 }\end{array}$ & 97.61 \\
\hline
\end{tabular}

that all isolates that share the same REP pattern were clonally related to a defined taxon. Six REP groups were designated and one representative strain per REP pattern was selected for further studies.

Th 16S rDNA sequences of the selected strains were compared to those available in the EZtaxon database and phylogenetic analysis placed all of these selected strains within the genus Paenibacillus. The similarities were ranging from $97.34 \%$ to $99.11 \%$ (Table 1 ). The phylogenetic tree was constructed by the neighbor-joining method as shown in Figure 2.

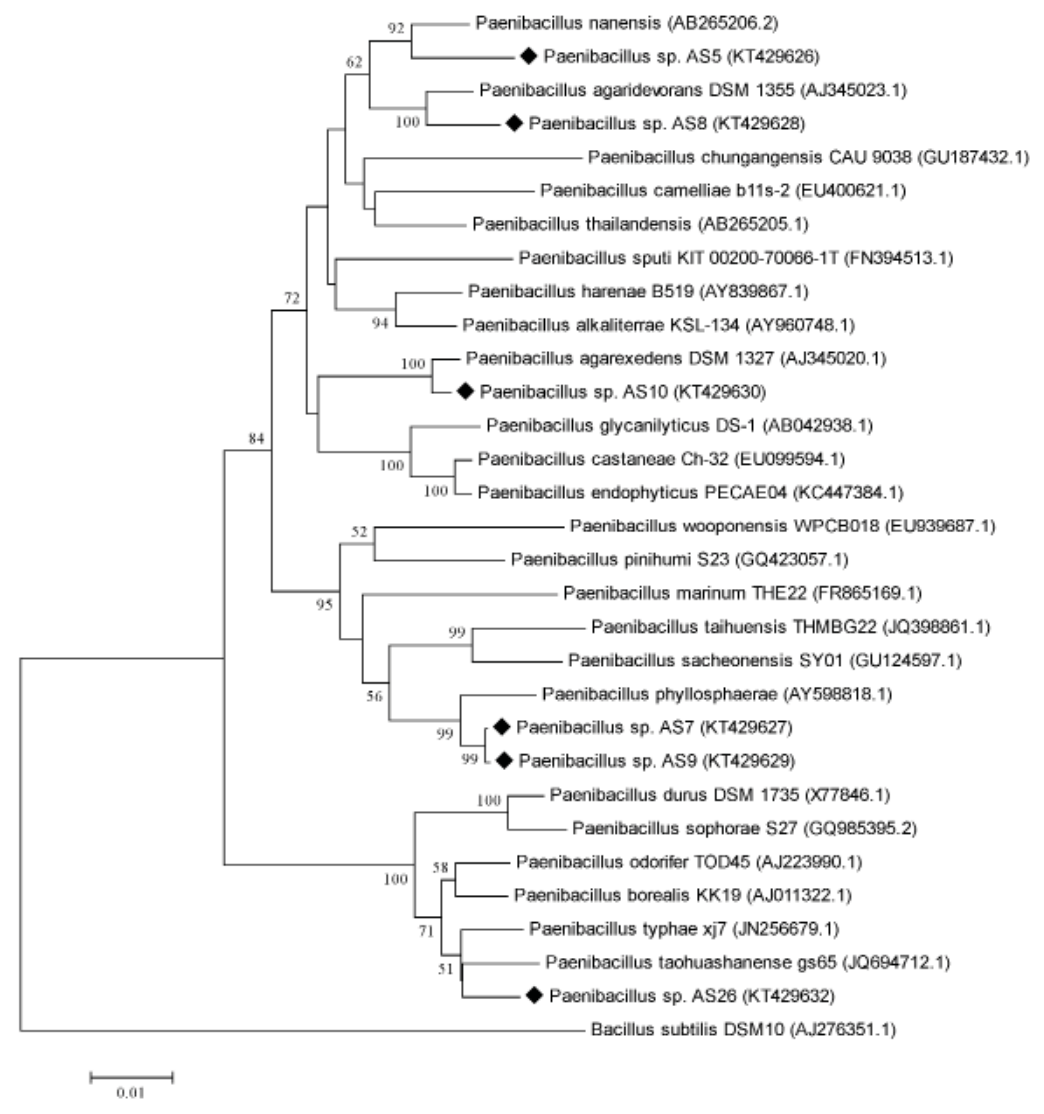

Figure 2. A neighbor-joining phylogenetic tree showing taxonomic relationships between selected strains and the related species belonging to the genus Paenibacillus based on 16S rRNA gene sequences. Bacillus subtilis DSM 10 was used as an out-group. Bootstrap analyses were performed with 1000 replications, only values $\geq 50 \%$ are shown. (Bar: 0.01 substitutions per nucleotide position). 

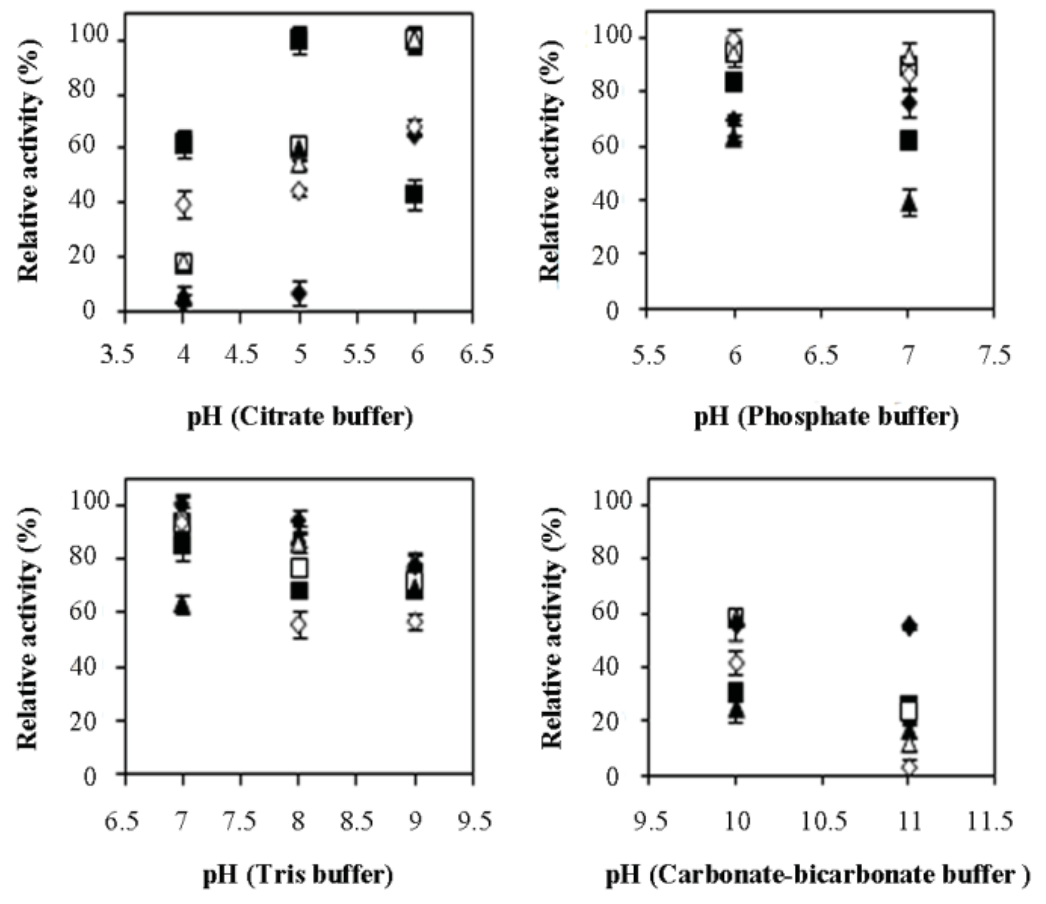

Figure 3. The effect of $\mathrm{pH}$ on the xanthanase activity of the selected strains of Paenibacillus spp. Xanthanase activity was assessed by measuring the release of reducing sugar using DNS method. Experiments were carried out at $30^{\circ} \mathrm{C}$ for $15 \mathrm{~min}$ in the following buffers with the concentration of $20 \mathrm{mmol}^{-1} \mathrm{~L}^{-1}$ Citrate, Phosphate, Tris, and Carbonate-bicarbonate for $\mathrm{pH}$ range of 4-6, 6-7, 7-9, and 10-11, respectively. AS5 (๘); AS7 (); AS8 (ム); AS9 $(\Delta) ; \operatorname{AS} 10(\diamond) ; \operatorname{AS} 26(\diamond)$.

\subsection{Xanthanase Characterization}

The xanthanolytic activity of the selected strains of the Paenibacillus spp. is depicted for the different $\mathrm{pH}$ values using different buffering solutions (Fig. 3). The strains exhibited maximum xanthanolytic activity within $\mathrm{pH}$ values ranging from 5 to 7 . In a number of strains, xanthanases have maintained a remarkable portion of their activity toward acidophilic or alkalophilic conditions. Xanthanase from Paenibacillus sp. AS5 has kept about $60 \%$ of its activity at $\mathrm{pH} 4$. However, Paenibacillus sp. AS7 has retained about $60 \%$ of xanthanse activity at $\mathrm{pH}$ 10 and showed $20 \%$ of its activity at $\mathrm{pH} 11$.

The selected strains showed different maximum xanthanolytic activities at a range of temperature changes from 35 to $45{ }^{\circ} \mathrm{C}$ (Fig. 4a). The strain AS5 showed the greatest thermophilic activity at $45{ }^{\circ} \mathrm{C}$ in addition to maintaining $40 \%$ of this activity at $50{ }^{\circ} \mathrm{C}$.

All strains showed their highest xanthanolytic activity in absence of additional salt $(\mathrm{NaCl})$ except for the strain AS5 which maintained its maximum enzyme activity up to 0.1 mol. $\mathrm{L}^{-1} \mathrm{NaCl}$ (Fig. $4 \mathrm{~b}$ ).

The xanthanase activity of the selected strains of the Paenibacillus spp. was measured under the optimum temperature, $\mathrm{pH}$ condition and in absence of additional salt $(\mathrm{NaCl})$. As well, their xanthan lyase activity was determined under constant conditions $\left(30^{\circ} \mathrm{C}\right.$ and Tris
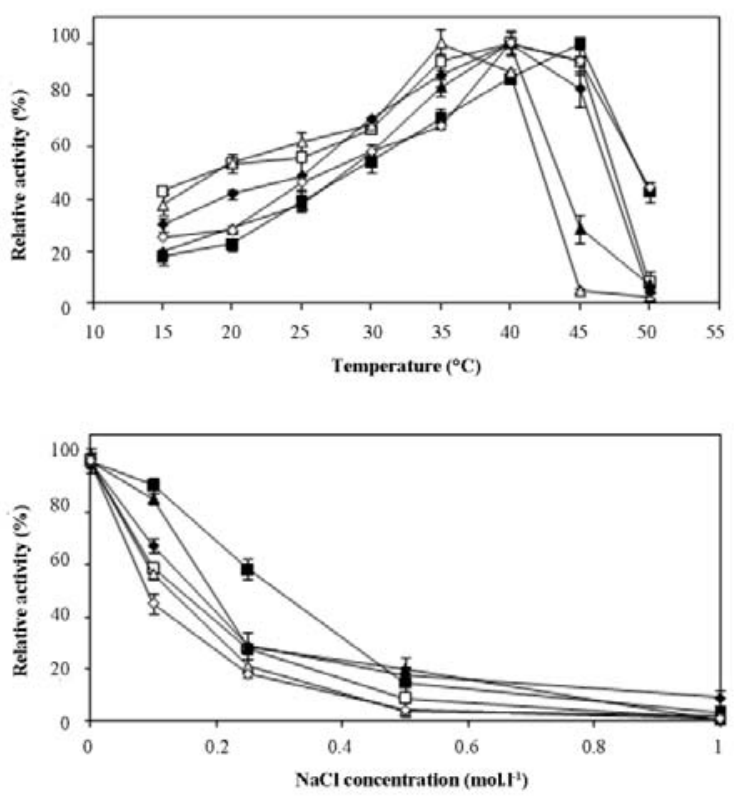

Figure 4. The effect of temperature and salinity on the xanthanase activity of the selected strains of Paenibacillus spp. Xanthanase activity was assessed by measuring the release of reducing sugar using DNS method. (5a): Experiments were carried out at various temperatures ranging from $15-55^{\circ} \mathrm{C}$. (5b): Reactions were carried out at different concentrations of salt ranging from 0 to $1 \mathrm{~mol} . \mathrm{L}^{-1} \mathrm{NaCl}$. AS5 $(\bullet)$; $\operatorname{AS} 7(\square)$; $\operatorname{AS} 8(\boldsymbol{\Delta})$; $\operatorname{AS} 9(\Delta)$; $\operatorname{AS} 10(\bullet) ; \operatorname{AS} 26(\diamond)$. 


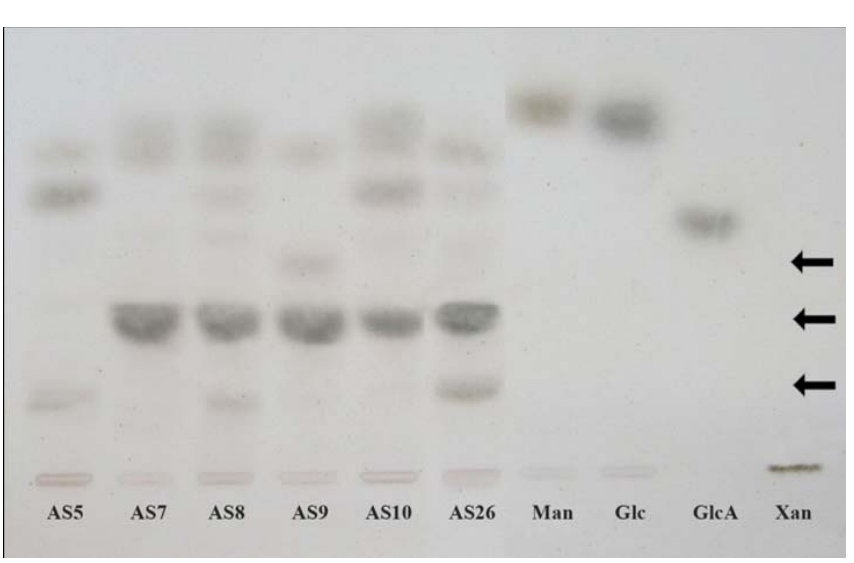

Figure 5. TLC analysis of xanthan depolymerization products which were produced by the strains of Paenibacillus species. The reaction was carried out at $30^{\circ} \mathrm{C}$ and a reaction mixture which contained equal volumes of the crude enzyme and $0.5 \%$ xanthan solution in phosphate buffer $\mathrm{pH} 7$. Arrows indicate xantho-oligosaccharides. Abbreviations: Man; D-mannose, Glc; D-glucose, GlcA; D-glucuronic acid, and Xan; Xanthan

buffer $\mathrm{pH}$ 7). Among the selected strains, Paenibacillus sp. AS7 has exhibited the highest xanthanase and xanthan lyase activity with 0.46 and 7.1 U.mL $\mathrm{mL}^{-1}$, respectively. In comparison, other strains showed lower xanthanse activity: AS9 >AS5 >AS10 >AS8 $>$ AS26 with $0.38,0.26,0.16,0.12$, and $0.1 \mathrm{U}^{\mathrm{m}} \mathrm{mL}^{-1}$, correspondingly. Paenibacillus sp. strain AS8 showed the lowest xanthan lyase activity with $0.32 \mathrm{U} \cdot \mathrm{mL}^{-1}$.

According to TLC analysis, the polymer was degraded into oligosaccharides and simple sugars by all strains. It was evident from the variations in the pattern of the bands and their intensities that the xanthanase and their related activities were different among the examined Paenibacilli isolates (Fig. 5).

\subsection{Biodegradation of other Polysaccharides}

All the xanthanase producing strains of Paenibacillus spp. were assessed for their catalytic activity against polysaccharides other than xanthan through application of a number of biopolymers. The obtained results have revealed the following activities: CMCase, xylanase, amylase, pectin lyase, and alginate lyase activities. Among the three type species obtained from the culture collection, only Paenibacillus agaridevorans could degrade xanthan.

\section{Discussion}

From 1998 to 2010, the surface area of Urmia Lake has been drastically diminished from $5650 \mathrm{Km}^{2}$ to about 2005 $\mathrm{Km}^{2}$, due to the construction of dams on rivers that flow into the lake and uncontrolled usage of ground water for agricultural application. According to statistical models and time series, the lake level will be further reduced about $3 \mathrm{~m}$ in 2100 and expansion of parched land could become a major crisis in the region (32). Thus, extinction of a large number of unknown bacteria and loss of useful genomes is of great concern. In an ecological crisis such as this, study of the biodiversity and possible applications of microorganisms inhabiting the region has become a priority.

A few halotolerant and halophilic plants and animals such as Dunaliella salina and Artemia urmiana grow in the hypersaline lake. Yet, a greater diversity of animals and plants exists around the lake within heterologous habitats from low salt soils to those of saturated salinity. According to the model introduced by Nankai et al. (26) the complete xanthan degradation demands the presence of a complex of five different enzymes collectively called xanthanase. Complete xanthan degrading bacteria are rare. Here, we introduced a number of Paenibacillus spp. as dominant xanthan degrading bacteria in the Urmia Lake.

Thus far, only two out of 182 species have been reported as xanthan degrading Paenibacillus spp. Paenibacillus alginolyticus XL-1 degrades the xanthan molecule side chains and apparently leaves the backbone intact (6). In another research by Muchová et al. (14) it was shown that extracellular depolymerase(s) of the Paenibacillus sp. XD could cause an evident viscosity drop in the xanthan solution.

In this research, selected strains have shown greater than $97 \%$ similarities in $16 \mathrm{~S}$ rDNA sequences, however, the final classification of the strains requires DNA-DNA hybridization before being recognized as the novel taxa (33).

The genus Paenibacillus has been reported to hydrolyze a variety of carbohydrates such as starch, hemicelluloses, cellulose, CMC, chitin, pectin, curdlan, pustulan, and pullulan $(34,36-38)$. However, apparently, none of the species in the genus have been examined for their xanthanolytic activity. Degradation of the xanthan by $P$. agaridevorans indicates that the xanthanolytic activity of type species in the genus should thoroughly be evaluated and their saccharolytic activity demands to be assessed.

Xanthanase complexes exhibit differences in their properties such as optimal $\mathrm{pH}$ and temperature of the activity and stability, as well as salt tolerance. While xanthanase complex of a halotolerant strain of Bacillus sp. strain K11 has shown a remarkable salt tolerance in the presence of $40 \mathrm{~g} . \mathrm{L}^{-1} \mathrm{NaCl}$, the xanthanase from Bacillus sp. strain 13-4 appears to be sensitive to the presence of salt (4). In addition, the presence of the salt has improved the tolerance of the mixed culture 
to the temperatures up to $65{ }^{\circ} \mathrm{C}$ (12). In the present study, Paenibacillus spp. has shown the greatest xanthanase activity in absence of $\mathrm{NaCl}$, but one of the strains (i.e., the strain AS5) has maintained the partial activity in presence of the salt. Halophilic xanthanses will be of great interest in the future researches. As previously reported, the optimum $\mathrm{pH}$ and temperature for xanthanase activity of a mixed culture were 5-6 and 35-45 ${ }^{\circ} \mathrm{C}$, respectively (11). However, the optimum temperature for xanthan degradation by a mixed culture as reported by Cadmus et al. (12) was found to be $50^{\circ} \mathrm{C}$. In a published European patent numbered as 0030 393, xanthanase complex remained active at a temperature between $25{ }^{\circ} \mathrm{C}$ and $70{ }^{\circ} \mathrm{C}$, preferably $30{ }^{\circ} \mathrm{C}$, and a $\mathrm{pH}$ between 5 and 7, preferably $\mathrm{pH}$ 5.6. The bacterial strains subjected to the examination by Cadmus et al. (4) were found to have maximum xanthanase activity at a temperature of $42{ }^{\circ} \mathrm{C}$ and a $\mathrm{pH}$ of 5.4. Also, no xanthanolytic activity was observed below $\mathrm{pH} 4$ or above $\mathrm{pH}$ 8. Moreover, the optimal $\mathrm{pH}$ and temperature for the xanthan degrading reaction in Cellulomonas sp. LX was 6 and $40{ }^{\circ} \mathrm{C}$, respectively (7). In the present study, the optimum temperature of xanthanase enzymes show a shift toward $35-45^{\circ} \mathrm{C}$. In addition, xanthanse complex from AS5 strain shows a partial activity at $55^{\circ} \mathrm{C}$. The optimum xanthanase activity of the strains was observed at the $\mathrm{pH} \mathrm{5-8.} \mathrm{The} \mathrm{alkalophilicity} \mathrm{of} \mathrm{the}$ xanthanase from the strain AS10 is a novel finding, plus the fact that the xanthanase from the strains AS5 and AS7 have maintained their partial activity at higher $\mathrm{pH}$ values up to 11 .

Xanthanase has found applications in the oil industry such as reduction of the viscosity of xanthan containing fluids and removal of the xanthan formation damage $(4,12,13,35)$. Xantho-oligosaccharides could induce phytoalexin accumulation in soybean cotyledon tissues, indicating their role as elicitor-active compounds (7). However, the applicability of the xantho-oligosaccharides in the management of plant diseases caused by $X$. campestris pv. campestris has been disputed (36).

Moreover, xantho-oligosaccharides, much like many other oligosaccharides, may find applications as prebiotics in food and feed. Similar to as chitooligosaccharides, they can be used as feedstock for production of certain pharmaceuticals. Furthermore, as an occupational hazardous material, xanthan dust induces allergy and its inhalation is health threatening to those people who work in small xanthan consuming industries. Healthcare management in such plants may demand xanthanase for complete removal of xanthan to prevent indoor pollution of air and surfaces.

\section{References}

1. García-Ochoa F, Santos VE, Casas JA, Gómez E. Xanthan gum: production, recovery, and properties. Biotechnol Adv. 2000; 18(7):549-579. DOI:10.1016/S0734-9750(00)00050-1

2. Lesley SM. Degradation of the polysaccharide of Xanthomonas phaseoli by an extracellular bacterial enzyme. Can J Microbiol. 1961; 7(5):815-825. DOI: 10.1139/m61-097

3. Cripps RE, Sommerville HJ, Holt MS. Xanthanase enzyme and its production. 1981; Eur. Pat. 0030,393.

4. Cadmus MC, Jackson LK, Burton KA, Plattner RD, Slodki ME. Biodegradation of xanthan gum by Bacillus sp. Appl Environ Microbiol. 1982; 44(1):5-11. DOI: 0099-2240/82/07000507\$02.00/0

5. Hashimoto W, Miki H, Tsuchiya N, Nankai H, Murata K. Xanthan lyase of Bacillus sp. strain GL1 liberates pyruvylated mannose from xanthan side chains. Appl Environ Microbiol. 1998; 64(10):3765-3768.

6. Ruijssenaars HJ, de Bont JAM, Hartmans S. A pyruvated mannose-specific xanthan lyase involved in xanthan degradation by Paenibacillus alginolyticus XL-1. Appl Environ Microbiol. 1999; 65(6):2446-2452.

7. Liu H, Huang C, Dong W, Du Y, Bai X, Li X. Biodegradation of xanthan by newly isolated Cellulomonas sp. LX, releasing elicitor-active xantho-oligosaccharides-induced phytoalexin synthesis in soybean cotyledons. Process Biochem. 2005; 40(12):3701-3706. DOI:10.1016/j.procbio.2005.05.006

8. Qian F, An L, Wang M, Li C, Li X. Isolation and characterization of a xanthan-degrading Microbacterium sp. strain XT11 from garden soil. J Appl Microbiol. 2007; 102(5):1362-1371. DOI:10.1111/j.1365-2672.2006.03215.x

9. Derekova A, Mandeva R, Kambourova M. Phylogenetic diversity of thermophilic carbohydrate degrading bacilli from Bulgarian hot springs. World J Microbiol Biotechnol. 2008; 24(9):1697-1702. DOI: 10.1007/s11274-008-9663-0

10. Chen X, Wang M, Yang F, Tang W, Li X. Isolation and characterization of xanthan-degrading Enterobacter sp. nov. LB37 for reducing the viscosity of xanthan in petroleum industry. World J Microbiol Biotechnol. 2014; 30(5):15491557. DOI: $10.1007 / \mathrm{s} 11274-013-1578-8$

11. Hou CT, Barnabe N, Greaney K. Biodegradation of xanthan by salt-tolerant aerobic microorganisms. J Ind Microbiol. 1986; 1(1):31-37. DOI: $10.1007 / \mathrm{BF} 01569414$

12. Cadmus MC, Slodki ME, Nicholson JJ. High-temperature, salttolerant xanthanase. J Ind Microbiol. 1989; 4(2):127-133. DOI: 10.1007/BF01569797

13. 13. Tjon-Joe-Pin RM, Carr MA, Yang B. Methods and materials for degrading xanthan, 2000; US Pat. Appl. 6,110,875.

14. Muchová M, Růžiĉka J, Julinová $M$, Doležalová $M$, Houser J, Koutný M, Buňková L. Xanthan and gellan degradation by bacteria of activated sludge. Water Sci Technol. 2009; 60(4):965-973. DOI: $10.2166 /$ wst.2009.44

15. Wilson K. Preparation of genomic DNA from bacteria. Curr Protoc Mol Biol. 2001; Chapter 2:Unit 2.4. DOI: 10.1002/0471142727.mb0204s56

16. Versalovic J, Koeuth T, Lupski JR. Distribution of repetitive DNA sequences in eubacteria and application to fingerprinting of bacterial genomes. Nucleic Acids Res. 1991; 19(24):68236831. DOI: 10.1093/nar/19.24.6823

17. Versalovic J, Kapur V, Mason EO, Shah U, Koeuth T, Lupski JR, Musser JM. Penicillin-resistant Streptococcus pneumoniae 


\section{Ashraf S et al.}

strains recovered in Houston: identification and molecular characterization of multiple clones. J Infect Dis. 1993; 167(4):850-856. DOI: 10.1093/infdis/167.4.850

18. Weisburg WG, Barns SM, Pelletier DA, Lane DJ. 16S ribosomal DNA amplification for phylogenetic study. J Bacteriol. 1991; 173(2):697-703. DOI: 0021-9193/91/020697-07\$02.00/0

19. Chun J, Lee JH, Jung Y, Kim M, Kim S, Kim BK, Lim YW. EzTaxon: a web-based tool for the identification of prokaryotes based on 16S ribosomal RNA gene sequences. Int J Syst Evol Microbiol. 2007; 57(10):2259-2261. DOI: 10.1099/ijs.0.649150

20. Thompson JD, Higgins DG, Gibson TJ. CLUSTAL W: improving the sensitivity of progressive multiple sequence alignment through sequence weighting, position-specific gap penalties and weight matrix choice. Nucleic Acids Res. 1994; 22(22):4673-4680. DOI: 10.1093/nar/22.22.4673

21. Saitou N, Nei M. The neighbor-joining method: a new method for reconstructing phylogenetic trees. Mol Biol Evol. 1987; 4(4):406-425. DOI: 0737-4038/87/0404-0007\$02.00

22. Tamura K, Peterson D, Peterson N, Stecher G, Nei M, Kumar S. MEGA5: molecular evolutionary genetics analysis using maximum likelihood, evolutionary distance, and maximum parsimony methods. Mol Biol Evol. 2011; 28(10):2731-2739. DOI: $10.1093 / \mathrm{molbev} / \mathrm{msr} 121$

23. Felsenstein J. Confidence limits on phylogenies: an approach using the bootstrap. Evolution. 1985; 39(4):783-791. DOI: $10.2307 / 2408678$

24. Miller GL. Use of Dinitrosalicylic acid reagent for determination of reducing sugar. Anal Chem. 1959; 31(3):426-428. DOI: 10.1021/ac60147a030

25. Gonçalves C, Rodriguez-Jasso RM, Gomes N, Teixeira JA, Belo I. Adaptation of dinitrosalicylic acid method to microtiter plates. Anal Methods. 2010; 2(12):2046-2048. DOI: 10.1039/ c0ay00525h

26. Nankai H, Hashimoto W, Miki H, Kawai S, Murata K. Microbial system for polysaccharide depolymerization: enzymatic route for xanthan depolymerization by Bacillus sp. strain GL1. Appl Environ Microbiol. 1999; 65(6):2520-2526.

27. Teather RM, Wood PJ. Use of Congo red-polysaccharide interactions in enumeration and characterization of cellulolytic bacteria from the bovine rumen. Appl Environ Microbiol. 1982; 43(4):777-780. DOI: 0099-2240/82/040777-04\$02.00/0

28. Ruijssenaars HJ, Hartmans S. Plate screening methods for the detection of polysaccharase-producing microorganisms. Appl Microbiol Biotechnol. 2001; 55(2):143-149. DOI: 10.1007/ s002530000477

29. Schlesner H, Bartels C, Sittig M, Dorsch M, Stackebrandt E. Taxonomic and phylogenetic studies on a new taxon of budding, hyphal Proteobacteria, Hirschia baltica gen. nov., sp. nov. Int $J$ Syst Bacteriol. 1990; 40(4):443-451. DOI: 10.1099/00207713-40-4-443

30. Sawant SS, Salunke BK, Kim BS. A rapid, sensitive, simple plate assay for detection of microbial alginate lyase activity. Enzyme Microb Technol. 2015; 77:8-13. DOI: 10.1016/j. enzmictec.2015.05.003

31. González-Candelas L, Cortell A, Ramon D. Construction of a recombinant wine yeast strain expressing a fungal pectate lyase gene. FEMS Microbiol Lett. 1995; 126(3):263-269. DOI: 10.1111/j.1574-6968.1995.tb07428.x

32. Tisseuil C, Roshan GR, Nasrabadi T, Asadpour GA. Statistical modeling of future lake level under climatic conditions, case study of Urmia Lake (Iran). Int J Environ Res. 2013; 7(1):69-80.

33. Stackebrandt E, Goebel BM. Taxonomic note: A place for DNA-DNA reassociation and 16S rRNA sequence analysis in the present species definition in bacteriology. Int J Sys Evol Microbiol. 1994; 44(4):846-849. DOI: 10.1099/00207713-444-846

34. De Vos P, Ludwig W, Schleifer KH, Whitman WB. Family IV. Paenibacillaceae. In: De Vos P, Garrity GM, Jones D, Krieg NR, Ludwig W, Rainey FA, Schleifer KH, Whitman WB, editors. Bergey's manual of systematic bacteriology. $2^{\text {nd }}$ ed. Springer Science+Business Media; 2009.p. 269-295. DOI: 10.1007/b92997

35. Cadmus MC, Slodki ME. Enzymic breakage of xanthan gum solution viscosity in the presence of salts. Dev Ind Microbiol. 1985; 26:281-289.

36. Qian F, An L, He X, Han Q, Li X. Antibacterial activity of xanthooligosaccharide cleaved from xanthan against phytopathogenic Xanthomonas campestris pv. campestris. Process Biochem. 2006; 41(7):1582-1588. DOI: 10.1016/j.procbio.2006.03.003 